\title{
Living cover crops have immediate impacts on soil microbial community structure and function
}

\author{
D.M. Finney, J.S. Buyer, and J.P. Kaye
}

\begin{abstract}
Cover cropping is a widely promoted strategy to enhance soil health in agricultural systems. Despite a substantial body of literature demonstrating links between cover crops and soil biology, an important component of soil health, research evaluating how specific cover crop species influence soil microbial communities remains limited.This study examined the effects of eight fall-sown cover crop species grown singly and in multispecies mixtures on microbial community structure and soil biological activity using phospholipid fatty acid (PLFA) profiles and daily respiration rates, respectively. Fourteen cover crop treatments and a no cover crop control were established in August of 2011 and 2012 on adjacent fields in central Pennsylvania following spring oats (Avena sativa L.). Soil communities were sampled from bulk soil collected to a depth of $20 \mathrm{~cm}$ (7.9 in) in fall and spring, approximately two and nine months after cover crop planting and prior to cover crop termination. In both fall and spring, cover crops led to an increase in total PLFA concentration relative to the arable weed community present in control plots (increases of $5.37 \mathrm{nmol} \mathrm{g}^{-1}$ and $10.20 \mathrm{nmol} \mathrm{g}^{-1}$, respectively). While there was a positive correlation between aboveground plant biomass (whether from arable weeds or cover crops) and total PLFA concentration, we also found that individual cover crop species favored particular microbial functional groups. Arbuscular mycorrhizal (AM) fungi were more abundant beneath oat and cereal rye (Secale cereale L.) cover crops. Non-AM fungi were positively associated with hairy vetch (Vicia villosa L.). These cover crop-microbial group associations were present not only in monocultures, but also multispecies cover crop mixtures. Arable weed communities were associated with higher proportions of actinomycetes and Gram-positive bacteria. Soil biological activity varied by treatment and was positively correlated with both the size and composition (fungal:bacterial ratio) of the microbial community. This research establishes a clear link between cover crops, microbial communities, and soil health. We have shown that while cover crops generally promote microbial biomass and activity, there are species-specific cover crop effects on soil microbial community composition that ultimately influence soil biological activity. This discovery paves the way for intentional management of the soil microbiome to enhance soil health through cover crop selection.
\end{abstract}

Key words: cover crops—phospholipid fatty acid analysis—soil biological activity—soil health-soil microbial communities

\begin{abstract}
Building healthy, resilient soils is a central focus of US soil conservation programs, and cover cropping is a core strategy promoted to enhance physical, chemical, and biological properties of managed soils (Lehman et al. 2015a; USDA NRCS 2012). While considerable research has shown that including cover crops in a crop rotation influences soil biology, understanding of cover crop species-specific effects on soil
\end{abstract}

microbial community size, composition, and function and the time frame in which these effects are manifest remains limited. There is a critical need to identify how cover crop selection shapes soil microbial communities in order to develop efficient and effective management strategies that will lead to the restoration of healthy microbial communities in agricultural systems (Lehman et al. 2015b). This study examined the effects of eight fall-sown cover crop species grown singly and combined in multispecies mixtures on the size, composition, and function of soil microbial communities in living cover crop stands.

Soil health is defined as "the continued capacity of soil to function as a vital living system, within ecosystem and land-use boundaries, to sustain biological productivity, maintain the quality of air and water environments, and promote plant, animal, and human health" (Doran et al. 1996). This concept recognizes the central role that soil biota play in providing ecosystem services that are critical to agricultural systems such as nutrient retention and provision, disease suppression, enhancement of soil structure and stability, and weed management (Lehman et al. 2015b). A number of soil organisms contribute functions that ultimately provide these services, including a diverse array of soil microorganisms. Though linking structural features of soil microbial communities (i.e., biomass and composition) to specific soil functions remains an open field of investigation (Lehman et al. 2015a), soil health management recommendations frequently target the following two goals for the soil microbial community: increasing microbial biomass and enhancing microbial diversity (USDA NRCS 2012).

Plant communities are a primary source of the carbon (C) supporting microbial growth and activity; therefore, crop management can be used to promote increases in the size of the soil microbial community in agricultural systems. For instance, a recent meta-analysis demonstrated that crop rotations increase soil microbial biomass by an average of $21 \%$ relative to monocultures (McDaniel et al.2014b). This same analysis also demonstrated a strong influence of cover crops on this rotational effect, as cover crops led to an $8.5 \%$ increase in total soil C (McDaniel et al. 2014b). Cover crops are typically unharvested crops planted between cash crops that augment $\mathrm{C}$ provisioning to the soil system not only via
Denise M. Finney is an assistant professor in the Biology Department at Ursinus College, Collegeville, Pennsylvania. Jeffrey S. Buyer is a research chemist at the USDA Agricultural Research Service (ARS) Sustainable Agricultural Systems Laboratory, Beltsville, Maryland. Jason P. Kaye is a professor in the Department of Ecosystem Science and Management at Penn State University, University Park, Pennsylvania. 
unharvested residues, but also during active cover crop growth. During the latter period, $\mathrm{C}$ inputs derived from root exudation, fine root turnover, and litter decomposition may be sufficient to promote increases in soil microbial biomass (Wardle et al. 2004; Buyer et al. 2010; Maul and Drinkwater 2010; Kong and Six 2012). Despite this universally recognized link between plant and microbial communities, very few studies have actually examined microbial communities in living cover crop stands (Schutter et al. 2001; Lehman et al.2012). Much of our knowledge of relationships between cover crops and soil communities is based on studies of legacy effects of cover crop residues, the results of which may be convoluted by complex interactions between cover crops and other management factors that influence microbial communities such as tillage (Treonis et al. 2010; Wortman et al. 2013; Lienhard et al. 2014) and fertility amendments (Grayston et al. 2004; Saison et al. 2006; Carrera et al. 2007). Studies designed to isolate cover crop-specific effects on microbial communities from other influential management practices are essential to building our understanding of interactions between cover crops and microbes.

A diverse soil microbial community is viewed as capable of providing a broad range of functions and demonstrating greater resilience of those functions to physical and chemical disturbance (Lehman et al. 2015a). While there is no "optimal composition" for a healthy microbial community, promotion of certain microbial groups has been shown to enhance soil health. For example, arbuscular mycorrhizal fungi (AM fungi) enhance crop production by protecting host plants from pathogens, improving nutrient uptake, and increasing host plant tolerance to environmental stresses such as drought (Rillig 2004). Previous studies offer evidence that cover crops, and particularly grass species such as oat (Avena sativa L. [Kabir and Koide 2002; Lehman et al. 2012]), cereal rye (Secale cereale L. [White and Weil 2010]), and winter wheat (Triticum aestivum L. [Kabir and Koide 2000]), can, in fact, increase AM fungi in agricultural soils. Promoting the establishment of fungal communities in agricultural soils may also promote soil health more generally. A key indicator of soil health is soil organic matter (SOM), increases in which lead to enhanced nutrient cycling, aggregate stability, and water-holding capacity (Lehman et al. 2015b). Both the quantity and quality of SOM are improved in fungal-dominated microbial communities (Six et al. 2006). Crop rotation has been shown to influence the relative abundances of fungi and bacteria in agricultural systems (Tiemann et al. 2015); however, the significance of cover crops to this outcome remains unknown. Research in unfertilized grasslands has demonstrated that fungal communities respond positively to plant-derived C inputs, suggesting that inclusion of cover crops in a rotation may promote fungal community development (Denef et al. 2009), and previous studies have shown increases in fungal population density in some cover cropping systems (Schutter et al. 2001; Buyer et al. 2010). The fact that certain cover crop species have been associated with increases in fungal groups suggests that cover crop selection could play an important role in managing soils for greater fungal dominance.

Phospholipid fatty acid (PLFA) analysis has been widely used to assess the composition of microbial communities in agricultural systems and community response to cover crops (Bossio et al. 1998; Schutter et al. 2001; Buyer et al. 2010; Treonis et al. 2010; Lehman et al. 2012; Wortman et al. 2013). Phospholipids are a component of all cellular membranes, and signature phospholipids are found in the membranes of specific microbial groups. Quantifying these "biomarkers" provides a means of determining the abundance of different bacterial and fungal groups, as well as protozoans in a soil community (Zelles 1999). Though other molecular techniques may provide a more detailed description of microbial diversity, PLFA offers the advantages of quantifying the total microbial biomass, providing a fungal:bacterial ratio, and lower cost. The recent development of high throughput PLFA analysis is likely to further increase the cost-effectiveness and utility of this tool (Buyer and Sasser 2012).

One impediment to translating our current knowledge of the relationships between cover crops and microbes into management strategies to effectively promote soil health is the fact that the number of cover crops included in any single study is often limited. This limitation makes it difficult to determine if observed effects are generalizable across cover crop species or actually species-specific. The latter is a reasonable expectation based on evidence that plant influences on belowground communi- ties are often species-specific (Wardle et al. 2004; Berg and Smalla 2009; Eisenhauer et al. 2010; Bezemer et al. 2010; Maul and Drinkwater 2010). Recognizing that management and environmental factors such as soil $\mathrm{pH}$ (Fierer and Jackson 2006), soil type (Buyer et al. 2002; Girvan et al. 2003), and climate (Drenovsky et al. 2004; McDaniel et al. 2014a) also mediate soil microbial communities, studies comparing a greater number of cover crops within a uniform management and environmental context are critical to unraveling the links among cover crops, microbes, and soil health.

This study examined the effects of eight fall-sown cover crop species grown singly and combined in multispecies mixtures on the size, composition, and function of soil microbial communities. PLFA analysis was used to characterize the structure of microbial communities present in the bulk soil of living cover crop stands approximately two and nine months after planting, prior to cover crop termination. We expected that the presence of cover crops would lead to increased microbial biomass and changes in community composition compared to the arable weed community present in an untilled fallow control. We further expected that species-specific plant effects would lead to variation in community composition across treatments. Short-term laboratory incubation was used to determine if changes in microbial community structure resulted in changes in biological activity, an important indicator of soil health. The results of this study provide much-needed information for land managers to guide the selection of cover crop species that will enhance soil health.

\section{Materials and Methods}

Field Experiment. We conducted a twoyear field study of cover crop diversity at the Russell E. Larson Agricultural Research Center near Rock Springs, Pennsylvania, United States, as described in Finney et al. (2016). A total of 17 (2011 to 2012) and 18 (2012 to 2013) cover crop treatments were planted in adjacent fields (i.e., different fields were used for each year of the study) in late August within an oat-corn (Zea mays L.) cash crop rotation following small grain harvest. We selected a subset of these treatments (15) including the no cover control (an untilled weedy fallow), eight species grown in monocultures, and six mixtures composed of the monoculture species for microbial 
community analysis (table 1). Cover crop treatments were established in $9.1 \times 6.5 \mathrm{~m}$ $(30 \times 21 \mathrm{ft})$ plots in a randomized complete block design replicated four times. Each site was moldboard plowed and disked before cover crop planting. We planted all cover crop treatments with a drill fitted with a cone seed distributor and mixed legume seed with dry inoculant before planting. Cover crops were terminated with glyphosate and subsequently incorporated prior to corn planting the following spring. All soil subject to microbial community analysis was collected prior to cover crop termination (see below). We also measured cover crop and arable weed biomass in fall prior to the first killing frost and spring immediately prior to termination by clipping within quadrats. Aboveground biomass data have previously been reported in Finney et al. (2016).

Soil Sampling. Bulk soil samples were collected in fall at the time of peak cover crop growth and spring approximately one week prior to cover crop termination. At each sampling event, we collected 12 cores $(0.20$ $\mathrm{m}$ depth by $0.02 \mathrm{~m}$ inside diameter [7.9 in depth by 0.79 in inside diamter]) from each experimental plot (six cores from within the cover crop row and six cores from between cover crop rows) and homogenized cores in a plastic bag. We placed samples in coolers for temporary storage in the field and transport to the lab. In the lab, we stored samples at $4^{\circ} \mathrm{C}$ $\left(39.2^{\circ} \mathrm{F}\right)$ for no more than 24 hours prior to laboratory processing. We sieved homogenized samples to $2 \mathrm{~mm}$ (0.07 in). A $50 \mathrm{~g}$ (1.8 oz) subsample was transferred to a sterile specimen cup and stored at $-20^{\circ} \mathrm{C}\left(-4^{\circ} \mathrm{F}\right)$ for PLFA analysis. A $100 \mathrm{~g}$ (3.5 oz) subsample was transferred to a fresh plastic bag and stored at $4^{\circ} \mathrm{C}\left(39.2^{\circ} \mathrm{F}\right)$ for laboratory incubation.

Soil sampling and laboratory processing were conducted in an aseptic manner to the extent possible. Specifically, we wore latex gloves during field sampling and rinsed soil probes with $70 \%$ reagent alcohol prior to collection from each plot. Similarly, we wore latex gloves for lab activities and changed gloves between samples. Lab equipment (soil sieves and spoons) was washed with soap and water to remove soil particles, subsequently rinsed in a $10 \%$ sodium hypochlorite $(\mathrm{NaClO})$ solution, and air-dried between samples.

Phospholipid Fatty Acid Analysis. We used PLFA analysis to determine the size and structure of the soil microbial community associated with each cover crop treatment.

\section{Table 1}

Species composition and seeding rates of cover crop monocultures and mixtures planted in August of 2011 and 2012 on adjacent fields following oat in central Pennsylvania.

\begin{tabular}{|c|c|c|c|c|c|c|c|c|}
\hline \multirow[b]{2}{*}{ Treatment } & \multicolumn{8}{|c|}{ Seeding rate $\left(\mathrm{kg} \mathrm{ha}^{-1}\right)$} \\
\hline & SH & SB & RC & HV & $\mathbf{F R}$ & $\mathbf{O A}$ & $\mathbf{C A}$ & CR \\
\hline \multicolumn{9}{|l|}{ No cover crop } \\
\hline Sunn hemp (SH) & 22 & & & & & & & \\
\hline Soybean (SB) & & 90 & & & & & & \\
\hline Red clover (RC) & & & 13 & & & & & \\
\hline Hairy vetch (HV) & & & & 28 & & & & \\
\hline Forage radish (FR) & & & & & 11 & & & \\
\hline Oat $(\mathrm{OA})$ & & & & & & 125 & & \\
\hline Canola (CA) & & & & & & & 12 & \\
\hline Cereal rye (CR) & & & & & & & & 134 \\
\hline $\mathrm{FR}+\mathrm{OA}+\mathrm{CA}+\mathrm{CR}$ & & & & & 3 & 63 & 5 & 67 \\
\hline $\mathrm{SH}+\mathrm{SB}+\mathrm{FR}+\mathrm{OA}$ & 11 & 45 & & & 3 & 63 & & \\
\hline $\mathrm{RC}+\mathrm{HV}+\mathrm{CA}+\mathrm{CR}$ & & & 5 & 11 & & & 5 & 67 \\
\hline $\mathrm{SH}+\mathrm{SB}+\mathrm{CA}+\mathrm{CR}$ & 11 & 45 & & & & & 5 & 67 \\
\hline $\mathrm{RC}+\mathrm{HV}+\mathrm{FR}+\mathrm{OA}$ & & & 5 & 11 & 3 & 63 & & \\
\hline 8 species mix & 11 & 45 & 5 & 11 & 3 & 63 & 5 & 67 \\
\hline
\end{tabular}

High-throughput PFLA was performed as described in Buyer and Sasser (2012). Briefly, $\sim 2 \mathrm{~g}(0.1 \mathrm{oz})$ lyophilized soil was extracted with $4 \mathrm{ml}(0.135 \mathrm{fl} \mathrm{oz})$ Bligh-Dyer extractant and the resulting liquid phase separated with $1 \mathrm{ml}(0.034 \mathrm{fl} \mathrm{oz})$ each of chloroform and deionized water. The top aqueous phase was aspirated and the bottom lipid-containing phase dried. Lipid classes were separated by solid phase extraction (SPE) chromatography in a 96-well plate with $50 \mathrm{mg}(0.002 \mathrm{oz})$ silica gel per well (Phenomonex, Torrence, California). Lipids were dissolved in chloroform and samples passed through the silica gel prior to washing with $1 \mathrm{~mL}(0.034 \mathrm{fl} \mathrm{oz})$ chloroform and $1 \mathrm{~mL}$ acetone. Phospholipids were then eluted with $0.5 \mathrm{ml}(0.017 \mathrm{fl} \mathrm{oz})$ 5:5:1 methanol:chloroform:deionized water into $1.5 \mathrm{ml}(0.051 \mathrm{fl} \mathrm{oz})$ vials and dried in vacuo. Following addition of $0.2 \mathrm{ml}(0.007 \mathrm{fl}$ $\mathrm{oz})$ transesterification reagent and incubating for 15 minutes at $37^{\circ} \mathrm{C}, 0.4 \mathrm{ml}(0.014 \mathrm{fl} \mathrm{oz})$ $0.075 \mathrm{M}$ acetic acid was added, and samples were extracted twice with $0.4 \mathrm{ml}$ chloroform. Chloroform was removed by drying and lipids dissolved in $75 \mu$ l hexane prior to transfer to gas chromatography vials with conical inserts. Samples were stored at $-20^{\circ} \mathrm{C}$ $\left(-4^{\circ} \mathrm{F}\right)$ as needed during the extraction process and until analysis.

Samples were analyzed on an Agilent (Agilent Technologies, Wilmington, Delaware) 6890 gas chromatograph (GC) outfitted with an autosampler, split-splitless injector, and flame ionization detector. MIS Sherlock soft- ware (MIDI, Inc., Newark, Delaware) was used in conjunction with Agilent Chemstation to control the system for the analysis. Fatty acids were separated on an Agilent Ultra 2 column $(25 \mathrm{~m} \times 200 \mu \mathrm{m}$ inside diameter $\times 0.33 \mu \mathrm{m}$ film thickness) using hydrogen $(\mathrm{H})$ gas as the carrier $\left(1.2 \mathrm{ml} \mathrm{m^{-1 }}[0.04\right.$ $\mathrm{Oz} \mathrm{min}^{-1}$ ] flow rate) and identified using the MIDI PLFAD1 calibration mix and naming table. We also ran random samples on a Clarus 500 GC-MS (Perkin-Elmer, Waltham, Massachusetts, United States) to confirm fatty acid identification following the procedure of Buyer et al. (2010).

Laboratory Incubation. We conducted a seven day incubation of fresh soil to measure daily respiration rate, an indicator of soil biological activity (Weitzman et al. 2014). At initiation, $20 \mathrm{~g}(0.7 \mathrm{oz})$ of fresh soil was placed in a $100 \mathrm{~mL}(3.38 \mathrm{fl} \mathrm{oz})$ Wheaton serum bottle and adjusted to $50 \%$ water holding capacity (WHC) using deionized water. Each vial was capped with a butyl stopper, and an aluminum (Al) ring was used to create an air-tight seal. Vial headspace was sampled $(1 \mathrm{~mL})$ with a syringe at 24 hour intervals for the first 72 hours. Following each sample collection, the stopper was removed in order to flush accumulated carbon dioxide $\left(\mathrm{CO}_{2}\right)$ and replaced after approximately one hour. Following the 72 hour collection and subsequent flushing, the stopper was replaced and the bottle sealed until the final headspace sampling. Carbon dioxide concentrations in the headspace gas were quantified 
immediately after collection with an infrared gas analyzer (LI7000, LiCor, Inc., Lincoln, Nebraska). Incubation bottles were stored at room temperature in a dark cabinet through the course of the incubation. Cumulative $\mathrm{CO}_{2}-\mathrm{C}$ released during the first seven days of incubation was calculated by linear interpolation between headspace sampling dates. Results are presented as the daily respiration rate in grams of dry soil ( $\mu \mathrm{g} \mathrm{CO}_{2}-\mathrm{C} \mathrm{g}^{-1}$ soil $\mathrm{d}^{-1} \pm 1$ standard error of the mean).

Statistical Analysis. We used analysis of variance (ANOVA) to determine the effect of cover crop treatment on the size and activity of the soil microbial community. Total PLFA (the sum of all detected fatty acids expressed in $\mathrm{nmol} \mathrm{g}^{-1}$ soil) was the indicator of microbial community size. PLFA data were $\log$ transformed for analysis to meet assumptions of normality and least square means were back-transformed for presentation. The daily respiration rate in the seven day incubation ( $\mu \mathrm{g} \mathrm{CO}_{2}-\mathrm{C} \mathrm{g}^{-1}$ soil d $\mathrm{d}^{-1}$ ) was an indicator of biological activity. We used a mixed model with fixed effects of treatment and year and their interaction and a random effect of block nested within year to identify differences among treatments and between years within each season (i.e., separate analyses were conducted on fall and spring data). To account for an unbalanced design in PLFA data across years, interaction tests were performed excluding soybean (Glycine max [L.] Merr.) and sunn hemp (Crotolaria juncea L.) monocultures for which data were available only in Year 1. We also used contrast analysis to detect differences in size and activity between the no cover crop control and cover cropped treatments within each season. Separation of least square means was performed using Tukey's honestly significant difference (HSD) at $\alpha=0.05$ (Searle et al. 1980).

Using PLFA data, we assessed the effect of cover crop treatment on microbial community composition. For these analyses, PLFA peak areas were combined into biomarker groups following Buyer et al. (2010) as shown in table 2. We used ANOVA to detect differences in the concentration of biomarker groups between treatments using the mixed model approach described above. We also calculated the ratio of fungal to bacterial biomarkers for each community as the sum of AM and non-AM fungi biomarker concentrations divided by the sum of Grampositive, Gram-negative, and actinomycete biomarker concentrations. We performed

\section{Table 2}

Signature fatty acids used to identify soil microbial biomarker groups (Buyer et al 2010).

\begin{tabular}{|c|c|c|}
\hline Biomarker group & Signature fatty acids & Reference \\
\hline Gram-positive bacteria & Iso and anteiso branched fatty acids & Zelles 1999 \\
\hline Gram-negative bacteria & $\begin{array}{l}\text { Monounsaturated fatty acids, } \\
\text { cyclopropyl 17:0 and 19:0 }\end{array}$ & Zelles et al. 1997 \\
\hline Actinomycetes & 10-methyl $16: 0$ and 10 -methyl $18: 0$ & Zelles 1999 \\
\hline $\begin{array}{l}\text { Arbuscular mycorrhizal } \\
\text { (AM) fungi }\end{array}$ & $16: 1 \omega 5$ cis & Olsson 1999 \\
\hline Fungi (non-AM fungi) & $18: 2 \omega 6$ cis & Frostegard and Baath 1996 \\
\hline Protozoa & $20: 3 \omega 6$ cis and $20: 4 \omega 6$ cis & Ringelberg et al. 1997 \\
\hline
\end{tabular}

ANOVA on fungal:bacterial ratios using the same mixed model previously described to detect differences among treatments. To assess the influence of cover crop treatment on microbial community composition, we performed distance-based redundancy analysis (db-RDA) on biomarker groups. Redundancy analysis allowed us to assess microbial community responses specific to environmental changes associated with each cover crop treatment without incorporating community responses to other factors in the environment that were not influenced by treatment (McCune and Grace 2002). Distance-based RDA is differentiated from RDA by its use of distance measures other than Euclidean distance. Biomarker group concentrations were Hellinger-transformed prior to analysis. Treatment significance was tested using permutation tests (Borcard et al. 2011). We used a second db-RDA to determine how the quantity and identity of aboveground biomass impacted microbial community composition. Environmental variables included in this analysis were cover crop biomass by species and weed biomass. All redundancy analyses were performed by season using Gower distances and conditioned on block nested within year.

Spearman rank correlations were used to identify relationships between aboveground biomass production and total PLFA concentration, as well as relationships between microbial community structure (i.e., size as indicated by total PLFA concentration and composition as indicated by fungal:bacterial ratio) and daily respiration rate. All statistical analyses were conducted using $\mathrm{R}$ statistical software (R Development Core Team 2013).

\section{Results and Discussion}

Cover Crop Effects on Soil Microbial Biomass. The presence of cover crops increased microbial biomass (indicated by total PLFA concentration) relative to the no cover crop control. While total PLFA concentration did not vary among treatments in the fall, total concentrations were higher in cover cropped soils compared to the no cover crop control (estimated difference $=5.37 \mathrm{nmol}$ $\mathrm{g}^{-1}, p=0.04$; table 3 ) within approximately two months of planting. Results were similar in the spring; though total PLFA concentration did not vary among treatments, cover crops led to an average increase of 10.22 nmol $\mathrm{g}^{-1}$ relative to the control $(p<0.01$; table 4). Total PLFA concentration varied by year in the spring, indicating greater overall microbial biomass in Year 1 compared to Year 2 (table 4). Such variability due to year was not unexpected given differences in climate and soil conditions between sites (Buyer et al. 2002; Drenovsky et al. 2004).

There was a positive correlation between total aboveground plant biomass (the sum cover crop and weed biomass) and total PLFA within each season $(r=0.43 ; p<$ 0.01). This result is consistent with the broadly recognized link between aboveand belowground productivity (Wardle et al. 2004) and supports the general consensus that the presence of living plant biomass provides resources to support microbial populations during periods that would otherwise be fallow in an agricultural system (Lehman et al. 2015b).

Previous studies have found that cover crops can support increases in soil microbial biomass (McDaniel et al. 2014b); however, many cover crop studies have measured microbial biomass following cover crop termination (Ingels et al. 2005; Wang et al. 2007; Nair and Ngouajio 2012), or only observed cover crop effects after incorporation (Schutter et al. 2001). In this study we measured soil biological properties in living cover crop stands in order to isolate cover crop effects on microbial communities from 
Table 3

Effect of year and cover crop on least square means and standard errors (standard errors are values in parentheses) of phospholipid fatty acid (PLFA) concentration ( $\mathrm{nmol} \mathrm{g}^{-1}$ ) in bulk soil in fall approximately two months following cover crop planting in August of 2011 (Year 1) and August of 2012 (Year 2) in central Pennsylvania.

\begin{tabular}{|c|c|c|c|c|c|c|c|c|c|c|c|c|c|c|}
\hline Year/crop & \multicolumn{2}{|c|}{ Total PLFA } & \multicolumn{2}{|c|}{$\begin{array}{l}\text { Gram + } \\
\text { bacteria }\end{array}$} & \multicolumn{2}{|c|}{$\begin{array}{l}\text { Gram - } \\
\text { bacteria }\end{array}$} & \multicolumn{2}{|c|}{ Actinomycetes } & \multicolumn{2}{|c|}{$\begin{array}{l}\text { Non-AM } \\
\text { fungi }\end{array}$} & \multicolumn{2}{|c|}{ AM fungi } & \multicolumn{2}{|c|}{ Protozoa } \\
\hline Year 1 & \multicolumn{2}{|c|}{$71.66(0.69)$} & \multicolumn{2}{|c|}{$17.40(0.18) b$} & \multicolumn{2}{|c|}{$21.90(0.24)$} & \multicolumn{2}{|c|}{$9.95(0.10) b$} & \multicolumn{2}{|c|}{$1.21(0.04) a$} & \multicolumn{2}{|c|}{$2.95(0.04)$} & \multicolumn{2}{|c|}{$0.76(0.02) \mathrm{a}$} \\
\hline No cover crop & \multicolumn{2}{|c|}{69.54 (1.49) } & \multicolumn{2}{|c|}{$17.81(0.37)$} & \multicolumn{2}{|c|}{$21.48(0.53)$} & \multicolumn{2}{|c|}{$10.98(0.35)$} & \multicolumn{2}{|c|}{$0.76(0.09)$} & \multicolumn{2}{|c|}{$2.71(0.08)$} & \multicolumn{2}{|c|}{$0.55(0.05)$} \\
\hline Sunn hemp (SH) & \multicolumn{2}{|c|}{73.88 (1.97) } & \multicolumn{2}{|c|}{$19.28(0.66)$} & \multicolumn{2}{|c|}{$22.24(0.51)$} & \multicolumn{2}{|c|}{$11.38(0.18)$} & 0.87 & $(0.04)$ & 2.97 & $(0.04)$ & 0.57 & $(0.02)$ \\
\hline Soybean (SB) & 72.7 & $(1.30)$ & 18.8 & (0.63) & 22.5 & $(0.31)$ & 11.0 & $(0.32)$ & 0.90 & $(0.12)$ & 2.93 & $(0.10)$ & 0.59 & $(0.05)$ \\
\hline Forage radish (FR) & 73.5 & $(2.27)$ & 18.2 & $(0.56)$ & 23.0 & $3(0.80)$ & 10.8 & $(0.32)$ & 1.13 & $(0.20)$ & 2.91 & $(0.11)$ & 0.59 & $(0.06)$ \\
\hline Oat $(\mathrm{OA})$ & 78.1 & $(2.16)$ & 19.4 & $(0.76)$ & 24.3 & $(0.80)$ & 11.3 & $(0.64)$ & 1.23 & (0.15) & 3.26 & $(0.14)$ & 0.60 & $(0.11)$ \\
\hline Canola (CA) & 74.7 & (1.92) & 18.9 & $(0.56)$ & 23.2 & $3(0.77)$ & 10.9 & $(0.55)$ & 1.01 & (0.11) & 2.86 & $(0.08)$ & 0.61 & $(0.06)$ \\
\hline Cereal rye (CR) & 74.0 & $(4.41)$ & 18.3 & $(1.27)$ & 23.0 & (1.64) & 10.6 & $3(0.66)$ & 1.11 & $(0.12)$ & 2.96 & $(0.15)$ & 0.63 & $(0.04)$ \\
\hline $\mathrm{FR}+\mathrm{OA}+\mathrm{CA}+\mathrm{CR}$ & 74.5 & (3.38) & 18.8 & (0.99) & 23.2 & (1.09) & 10.8 & $(0.51)$ & 0.95 & $(0.12)$ & 3.10 & $(0.20)$ & 0.65 & $(0.06)$ \\
\hline $\mathrm{RC}+\mathrm{HV}+\mathrm{FR}+\mathrm{OA}$ & 76.5 & $(2.83)$ & 19.4 & (1.01) & 23.4 & (1.04) & 11.2 & $3(0.68)$ & 0.97 & $(0.10)$ & 3.20 & $(0.13)$ & 0.75 & $(0.06)$ \\
\hline 8 species mix & 78.1 & $(3.59)$ & 19.3 & $(1.07)$ & 24.6 & $(1.21)$ & 11.1 & $(0.66)$ & 1.16 & $(0.21)$ & 3.14 & $0.17)$ & 0.76 & $(0.07)$ \\
\hline Contrast & Est. & $p$-value & Est. & $p$-value & Est. & $p$-value & Est. & $p$-value & Est. & $p$-value & Est. & $p$-value & Est. & $p$-value \\
\hline $\begin{array}{l}\text { Cover crops vs. } \\
\text { no cover crop } \\
\text { control }(\mathrm{df}=76)\end{array}$ & 5.37 & 0.04 & 1.11 & 0.14 & 1.68 & 0.04 & 0.04 & 0.93 & 0.28 & $<0.01$ & 0.31 & 0.02 & 0.09 & 0.11 \\
\hline
\end{tabular}

Notes: Gram + = Gram positive. Gram - = Gram negative. AM = arbuscular mycorrhizal. df = degrees of freedom. Est. = estimate. Values within a column with different letters were significantly different due to year or cover crop based on Tukey's honestly significant difference ( $p<0.05)$. The absence of letters in a column indicates that the effect of year or cover crop was not significant.

other management factors. During the cover crop season the primary sources of $\mathrm{C}$ inputs are root exudates and fine root turnover, which can positively impact microbial biomass (Buyer et al. 2010), but are considerably lower than $\mathrm{C}$ contributions from cover crop residues following termination. The effects of $\mathrm{C}$ inputs from standing crops are also likely to be stronger in the rhizosphere than in bulk soil (Kong and Six 2012). The fact that we detected differences between the control and cover cropped treatments in bulk soil collected prior to cover crop termination is notable. The results of this study indicate that the influence of cover crops on microbial communities is manifest on short timescales and extends beyond the rhizosphere.

Cover Crops and Microbial Community Composition. In addition to influencing overall microbial abundance, cover crops also led to increased concentrations of specific microbial groups. In the fall, concentrations of Gram-negative bacteria, non-AM fungi, and AM fungi were higher in cover cropped soils compared to the control (estimated dif- ference $=1.68, p=0.04$; estimated difference $=0.28, p<0.01$; and estimated difference $=$ $0.31, p=0.02$, respectively; table 3 ). Similar to the fall, concentrations of Gram-negative bacteria, non-AM fungi, and AM fungi were higher in the cover cropped treatments compared to the control in spring (estimated difference $=3.98, p<0.01$; estimated difference $=0.43, p=0.01 ;$ and estimated difference $=0.53, p<0.01$, respectively; table 4). By spring, cover cropped treatments also had, on average, higher concentrations of Gram-positive bacteria (estimated difference $=1.64, p=0.03$ ) and protozoa (estimated difference $=0.19, p=0.01)$ compared to the control. There were significant differences in the concentrations of Gram-negative bacteria, AM fungi, and non-AM fungi among individual treatments in the spring (table 4). Concentrations of each of these groups tended to be lowest in the no cover crop control (table 4). The abundance of microbial groups also varied by year (tables 3 and 4). In both seasons, we observed higher concentrations of non-AM fungi,AM fungi, and protozoa in Year 1, though the difference was not significant for AM fungi in the fall (tables 3 and 4). In the fall, abundances of Grampositive bacteria and actinomycetes were higher in Year 2 compared to Year 1 (table 3). The opposite pattern was observed in spring; abundances of Gram-positive bacteria and actinomycetes as well as Gram-negative bacteria were higher in Year 1, following the same pattern as total PLFA concentration (table 4).

Distance-based RDA indicated that cover crop treatment was a significant predictor of microbial community composition in both fall and spring (fall: $p=0.01$; spring: $p<$ $0.01)$. In both seasons, the first axis was significant (fall: $p<0.01$; spring: $p<0.01$ ) and separated treatments with high proportions of Gram-positive bacteria and actinomycetes from those with high proportions of Gram-negative bacteria, non-AM fungi, AM fungi, and protozoa (figures $1 \mathrm{a}$ and $1 \mathrm{~b}$ ). A differentiation of communities based on proportions of Gram-positive versus Gramnegative bacteria likely reflects the dominant metabolic strategy used by each of these bio- 
Table 4

Effect of year and cover crop on least square means and standard errors (standard errors are values in parentheses) of phospholipid fatty acid (PLFA) concentration ( $\mathrm{nmol} \mathrm{g}^{-1}$ ) in bulk soil in spring approximately nine months following cover crop planting in August of 2011 (Year 1) and August of 2012 (Year 2) in central Pennsylvania.

\begin{tabular}{|c|c|c|c|c|c|c|c|c|c|c|c|c|c|c|}
\hline Year/crop & \multicolumn{2}{|c|}{ Total PLFA } & \multicolumn{2}{|c|}{$\begin{array}{l}\text { Gram + } \\
\text { bacteria }\end{array}$} & \multicolumn{2}{|c|}{$\begin{array}{l}\text { Gram - } \\
\text { bacteria }\end{array}$} & \multicolumn{2}{|c|}{ Actinomycetes } & \multicolumn{2}{|c|}{$\begin{array}{l}\text { Non-AM } \\
\text { fungi }\end{array}$} & \multicolumn{2}{|c|}{ AM fungi } & \multicolumn{2}{|c|}{ Protozoa } \\
\hline Year 1 & \multicolumn{2}{|c|}{100.14 (1.28)a } & \multicolumn{2}{|c|}{25.14 (0.31)a } & \multicolumn{2}{|c|}{31.01 (0.44)a } & \multicolumn{2}{|c|}{$13.32(0.16) a$} & \multicolumn{2}{|c|}{$2.43(0.10) a$} & \multicolumn{2}{|c|}{4.19 (0.08)a } & \multicolumn{2}{|c|}{$1.05(0.04) \mathrm{a}$} \\
\hline Year 2 & \multicolumn{2}{|c|}{$73.53(1.43) b$} & \multicolumn{2}{|c|}{$18.54(0.33) b$} & \multicolumn{2}{|c|}{$23.38(0.49) b$} & \multicolumn{2}{|c|}{$10.92(0.23) b$} & \multicolumn{2}{|c|}{$1.21(0.09) b$} & \multicolumn{2}{|c|}{$2.72(0.07) b$} & \multicolumn{2}{|c|}{$0.47(0.03) \mathrm{b}$} \\
\hline No cover crop & \multicolumn{2}{|c|}{$77.32(6.29)$} & \multicolumn{2}{|c|}{$20.31(1.64)$} & \multicolumn{2}{|c|}{$23.48(1.96) b$} & \multicolumn{2}{|c|}{$11.67(0.72)$} & \multicolumn{2}{|c|}{$1.42(0.31) b c$} & \multicolumn{2}{|c|}{$2.96(0.33) b$} & \multicolumn{2}{|c|}{$0.58(0.08)$} \\
\hline Sunn hemp (SH) & \multicolumn{2}{|c|}{$85.89(5.44)$} & \multicolumn{2}{|c|}{$22.77(1.48)$} & \multicolumn{2}{|c|}{26.11 (1.87)ab } & \multicolumn{2}{|c|}{$12.47(0.80)$} & 1.81 & $.58) a b c$ & 3.40 & (0.25)ab & 0.54 & $(0.04)$ \\
\hline Soybean (SB) & 82.78 & $(5.36)$ & 21.6 & $(1.28)$ & 25.2 & (1.58)ab & 12.0 & $(0.77)$ & 1.70 & .28)abc & 3.26 & (0.35)ab & 0.68 & (0.11) \\
\hline Red clover (RC) & 86.20 & $(8.02)$ & 21.2 & (1.93) & 27.47 & (2.52)ab & 11.7 & $(0.80)$ & 1.90 & .35)abc & 3.40 & (0.45)ab & 0.67 & (0.11) \\
\hline Hairy vetch (HV) & 87.33 & (6.31) & 20.9 & $(1.56)$ & 27.7 & (1.93)ab & 11.5 & (0.68) & 2.60 & $.35) a$ & 3.25 & (0.32)ab & 0.86 & $(0.14)$ \\
\hline Forage radish (FR) & 84.98 & $(5.74)$ & 22.1 & $(1.56)$ & 26.2 & (1.48)ab & 12.0 & $(0.62)$ & 1.69 & .37)abc & 3.22 & (0.28)ab & 0.80 & $(0.22)$ \\
\hline Oat $(\mathrm{OA})$ & 88.13 & (5.75) & 22.8 & $(1.52)$ & 27.37 & (1.71)ab & 12.6 & $(0.73)$ & 1.28 & $.20) c$ & 3.66 & (0.33)a & 0.77 & $(0.13)$ \\
\hline Canola (CA) & 89.74 & (5.58) & 22.9 & (1.52) & 28.2 & (1.74)a & 12.6 & $(0.73)$ & 1.78 & .23)abc & 3.38 & (0.29)ab & 0.79 & 0.13) \\
\hline Cereal rye (CR) & 87.96 & (5.16) & 21.7 & (1.18) & 27.2 & (1.36)ab & 12.1 & (0.56) & 1.79 & $.30) a b c$ & 3.64 & (0.29)a & 0.82 & $(0.14)$ \\
\hline $\mathrm{FR}+\mathrm{OA}+\mathrm{CA}+\mathrm{CR}$ & 84.98 & (4.13) & 21.3 & $(1.00)$ & 26.6 & (1.11)ab & 12.1 & (0.54) & 1.40 & $.16) b c$ & 3.48 & (0.26)ab & 0.75 & (0.11) \\
\hline $\mathrm{SH}+\mathrm{SB}+\mathrm{FR}+\mathrm{OA}$ & 89.25 & $(5.72)$ & 22.6 & $(1.61)$ & 27.8 & (1.63)a & 12.5 & $(0.70)$ & 1.91 & .29)abc & 3.48 & (0.29)ab & 0.78 & (0.10) \\
\hline $\mathrm{RC}+\mathrm{HV}+\mathrm{CA}+\mathrm{CR}$ & 87.97 & (6.59) & 20.6 & $(1.47)$ & 28.3 & (2.03)a & 11.5 & $(0.75)$ & 2.41 & .43)ab & 3.54 & (0.36)ab & 0.77 & (0.11) \\
\hline $\mathrm{SH}+\mathrm{SB}+\mathrm{CA}+\mathrm{CR}$ & 86.26 & (6.16) & 21.5 & $(1.56)$ & 27.15 & (1.77)ab & 11.9 & $(0.72)$ & 1.52 & .22)abc & 3.56 & (0.36)ab & 0.74( & (0.13) \\
\hline $\mathrm{RC}+\mathrm{HV}+\mathrm{FR}+\mathrm{OA}$ & 89.26 & $(7.22)$ & 21.7 & $(1.56)$ & 28.5 & (2.40)a & 11.9 & (0.61) & 1.95 & .42)abc & 3.68 & (0.39)a & 0.90 & $(0.19)$ \\
\hline 8 species mix & 94.47 & $(7.61)$ & 22.9 & $(1.63)$ & 30.2 & (2.39)a & 12.6 & $(0.75)$ & 2.11 & .43)abc & 3.92 & $(0.44) a$ & 0.94 & $(0.19)$ \\
\hline Contrast & Est. & $p$-value & Est. & $p$-value & Est. & $p$-value & Est. & $p$-value & Est. & $p$-value & Est. & $p$-value & Est. & $p$-value \\
\hline $\begin{array}{l}\text { Cover crops vs. } \\
\text { no cover crop } \\
\text { control (df = 85) }\end{array}$ & 10.20 & $<0.01$ & 1.64 & 0.03 & 3.98 & $<0.01$ & 0.48 & 0.26 & 0.43 & 0.01 & 0.53 & $<0.01$ & 0.19 & 0.01 \\
\hline
\end{tabular}

Notes: Gram + = Gram positive. Gram - = Gram negative. AM = arbuscular mycorrhizal. Est. = estimate. Values within a column with different letters were significantly different due to year or cover crop based on Tukey's honestly significant difference $(p<0.05)$. The absence of letters in a column indicates that the effect of year or cover crop was not significant.

marker groups. Specifically, Gram-positive bacteria tend to be oligotrophic, utilizing more recalcitrant $\mathrm{C}$ sources, while Gramnegative bacteria tend to be copiotrophs that exploit more labile C sources (Fierer et al. 2007). In this study, contributions of labile $\mathrm{C}$ from cover crop root exudates and fine root turnover appear to have favored more copiotrophic microbial populations, as evidenced by the increase in Gram-negative bacteria associated with cover cropped treatments. Cover crops may have also influenced soil moisture, a physical soil factor that has been shown to influence the abundance of microbial groups (Lennon et al. 2012; Regan et al. 2014). Regardless of the mechanism, our findings of a positive response by Gramnegative bacteria to cover crops is consistent with previous studies (Buyer et al. 2010; Maul et al. 2014).

In both seasons, the no cover crop control was associated with higher proportions of Gram-positive bacteria and actinomycetes (figures $1 \mathrm{a}$ and $1 \mathrm{~b}$ ). This association may concur with work in grassland communi- ties, demonstrating that both of these groups were less involved in utilization of rhizodeposits than other microbial groups (Denef et al. 2009). This interpretation, however, does not wholly explain the observed results, as there were arable weed communities present in the no cover crop control that would also provide $\mathrm{C}$ via rhizodeposition. The fact that Gram-negative bacteria, both fungal groups, and protozoa were found in higher proportions in cover cropped treatments compared to the untilled control could suggest a potential antagonistic effect of arable weed communities on these microbial groups. Though research on relationships between arable weed communities and soil microbial communities is limited, previous research has found that arable weed communities do influence microbial community composition, and one notable effect is a reduction of AM fungi under arable weeds relative to cover crops (Wortman et al. 2013).

Both AM and non-AM fungi responded positively to the presence of a cover crop within approximately two months of plant- ing (table 3), and the relative abundance of fungi was an important factor in discriminating the composition of microbial communities associated with individual treatments in both fall and spring (figures $1 \mathrm{a}$ and $1 \mathrm{~b})$. By spring, the relative proportion of AM fungi versus non-AM fungi also served to differentiate individual treatments, indicated by the significance of axis two ( $p=$ 0.02 ; figure $1 \mathrm{~b}$ ). Observed concentrations of fungi (both AM and non-AM) tended to be lower than those of bacterial groups (tables 3 and 4), which most likely reflects the difference in the number of biomarkers used to identify fungi compared to bacteria. The generally positive association between cover crops and fungal communities may be indicative of conditions favorable for the recovery of these communities following tillage disturbance in cover cropped systems (Kabir et al. 1997; Schipanski et al. 2014). Cover crops also led to higher concentrations of the protozoan biomarkers in spring compared to the control (estimated difference $=0.19 \mathrm{nmol} \mathrm{g}^{-1}$, $p=0.01$; table 4 ), and this microbial group 


\section{Figure 1}

Distance-based redundancy analysis of soil microbial community composition as influenced by cover crop treatment in (a) fall and (b) spring, approximately two and nine months, respectively, after cover crop planting in 2011 and 2012 in central Pennsylvania. Vectors indicate the degree of correlation between each PLFA biomarker group (labeled in italics) and the axes. Axes labeled with an asterisk are significant. Labeled points represent the mean community composition of the corresponding treatment. $C A=$ canola. $C R=$ cereal rye. $F R=$ forage radish. $H V=$ hairy vetch. $\mathrm{NO}=$ no cover crop. $\mathrm{OA}=$ oat. $\mathrm{RC}=$ red clover. $\mathrm{SB}=$ soybean. $\mathrm{SH}=$ sunn hemp.

(a)

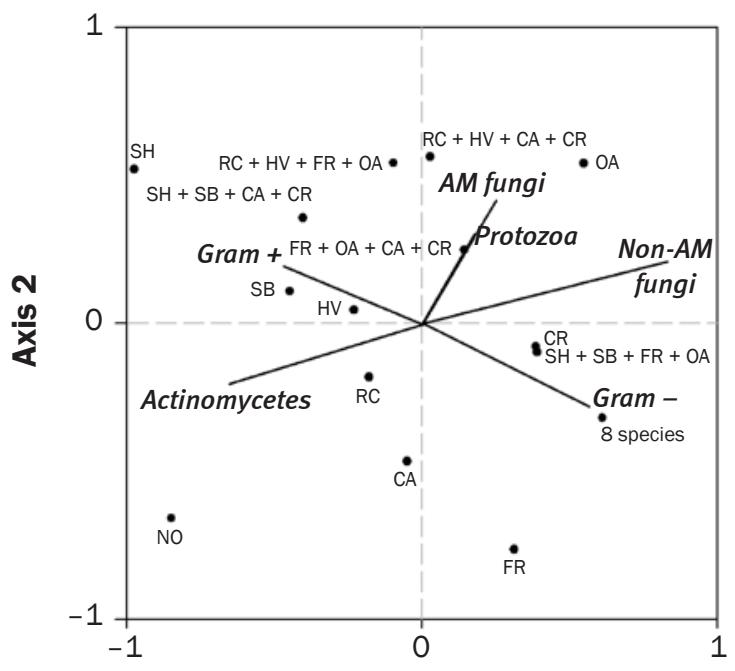

Axis 1* (b)

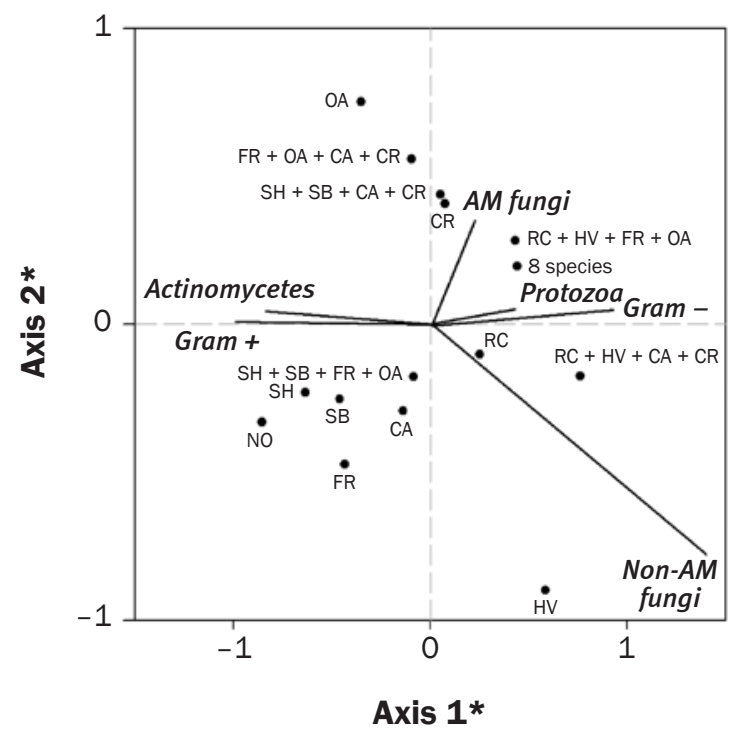

also contributed to the distinction of microbial communities among treatments in both fall and spring (figures $1 \mathrm{a}$ and $1 \mathrm{~b}$ ). Previous studies have similarly reported increases in protozoan abundance associated with cover cropping (Schutter et al. 2001; Carrera et al. 2007). Protozoans are bacterial grazers, therefore their increased abundance under cover crops may be due to the increased microbial biomass generally associated with cover cropped treatments in this study.

We also assessed microbial community composition using the ratio of fungal to bacterial PLFA biomarkers (Joergensen and Wichern 2008). In both fall and spring, the fungal:bacterial ratio averaged across treatments was higher in Year 1 than in Year 2 (table 5). Fungal:bacterial ratios did not vary among treatments in fall; however, cover crops led to an increase of 0.01 in the index value compared to the no cover crop control $(p=0.01$; table 5$)$. We observed the same increase in fungal:bacterial ratio from cover cropped treatments in spring $(p=0.03$; table 5). Additionally, in spring, the fungal:bacterial ratio was higher under the four species cover crop mixture that included hairy vetch (Vicia villosa L.), red clover (Trifolium pratense L.), cereal rye, and canola (Brassica napus L.) than the no cover crop control (table 5). The db-RDA had shown that most cover cropped treatments were associated with higher proportions of fungi compared to the no cover crop control (figures $1 \mathrm{a}$ and 1b); therefore, we expected that at least some cover cropped treatments would exhibit a higher fungal:bacterial ratio than the control. One explanation for the fact that compositional changes indicated by db-RDA did not manifest as differences in the fungal:bacterial ratio among treatments is that cover crops were associated not only with increased proportions of fungi, but also Gram-negative bacteria, which could offset increases in the overall ratio. Nonetheless, evidence of an increase in the relative abundance of fungi associated with cover crops provided by the $\mathrm{db}-\mathrm{RDA}$ and the increase in fungal:bacterial ratio observed in cover cropped treatments relative to the control suggest that cover crops can lead to greater fungal dominance, which in turn may promote SOM stabilization and enhance soil health (Six et al. 1999; Lehman et al. 2015b). As a whole, our analyses of microbial community composition clearly demonstrate that cover crops influenced the structure of microbial communities. Differences in the absolute and relative abundances of distinct microbial groups observed among treatments beg the question, "Do different cover crops influence different microbial groups?"- - a question we addressed with a second redundancy analysis.
Cover Crop Specific Influences on Soil Microbial Communities. Differences in microbial community composition among treatments suggest that there are speciesspecific relationships between cover crops and microbial communities. The second db-RDA demonstrated that the relative abundance of specific microbial groups within a season was related to quantity of biomass produced by specific cover crops and arable weeds (figures $2 \mathrm{a}$ and $2 \mathrm{~b}$ ), supporting this hypothesis. In this context, aboveground biomass of a particular species reflects the abundance of particular plant traits that may influence microbial abundance (e.g., root biomass, surface area, and exudates) and mediate the species-specific associations we observed. In both fall and spring, microbial communities were distinguished from one another based on whether they were dominated by Gram-positive bacteria and actinomycetes or by protozoa, AM-fungi, non-AM fungi, and Gram-negative bacteria (fall: $p<0.01$, spring: $p<0.01$; figures $2 \mathrm{a}$ and $2 \mathrm{~b}$, axis 1 in both panels). Cover crops contributing to high proportions of the latter groups in the fall were oat and forage radish (Raphanus sativus L.) (figure 2a). In contrast, red clover, hairy vetch, and sunn hemp cover crops were associated with Gram-positive bacteria and actinomycetes during the fall growing season (figure 2a). This differentiation may have 


\section{Table 5}

Effect of year and cover crop on least square means and standard errors (standard errors are values in parentheses) of the fungal:bacterial (F:B) ratio of soil microbial communities sampled in fall and spring, approximately two and nine months, respectively, following cover crop planting in August of 2011 (Year 1) and August of 2012 (Year 2) in central Pennsylvania.

\begin{tabular}{|c|c|c|c|c|c|c|}
\hline Year/crop & \multicolumn{3}{|l|}{ Fall } & \multicolumn{3}{|l|}{ Spring } \\
\hline Year 1 & \multicolumn{3}{|c|}{$0.08(0.00) a$} & \multicolumn{3}{|c|}{$0.10(0.00) a$} \\
\hline Year 2 & \multicolumn{3}{|c|}{$0.07(0.00) b$} & \multicolumn{3}{|c|}{$0.07(0.00) b$} \\
\hline No cover crop & \multicolumn{3}{|c|}{$0.07(0.00)$} & \multicolumn{3}{|c|}{$0.08(0.01) b$} \\
\hline Sunn hemp (SH) & \multicolumn{3}{|c|}{$0.07(0.00)$} & \multicolumn{3}{|c|}{0.08 (0.01)ab } \\
\hline Soybean (SB) & \multicolumn{3}{|c|}{$0.07(0.00)$} & \multicolumn{3}{|c|}{$0.08(0.00) a b$} \\
\hline Red clover (RC) & \multicolumn{3}{|c|}{$0.07(0.00)$} & \multicolumn{3}{|c|}{0.08 (0.01)ab } \\
\hline Hairy vetch (HV) & \multicolumn{3}{|c|}{$0.08(0.00)$} & \multicolumn{3}{|c|}{$0.10(0.00) a b$} \\
\hline Forage radish (FR) & \multicolumn{3}{|c|}{$0.08(0.00)$} & \multicolumn{3}{|c|}{0.08 (0.01)ab } \\
\hline Oat $(\mathrm{OA})$ & \multicolumn{3}{|c|}{$0.08(0.00)$} & \multicolumn{3}{|c|}{$0.08(0.00) a b$} \\
\hline Canola (CA) & \multicolumn{3}{|c|}{$0.07(0.00)$} & \multicolumn{3}{|c|}{$0.08(0.00) a b$} \\
\hline Cereal rye (CR) & \multicolumn{3}{|c|}{$0.08(0.01)$} & \multicolumn{3}{|c|}{0.09 (0.01)ab } \\
\hline $\mathrm{FR}+\mathrm{OA}+\mathrm{CA}+\mathrm{CR}$ & \multicolumn{3}{|c|}{$0.08(0.00)$} & \multicolumn{3}{|c|}{$0.08(0.00) a b$} \\
\hline $\mathrm{SH}+\mathrm{SB}+\mathrm{FR}+\mathrm{OA}$ & \multicolumn{3}{|c|}{$0.08(0.00)$} & \multicolumn{3}{|c|}{$0.08(0.00) a b$} \\
\hline $\mathrm{RC}+\mathrm{HV}+\mathrm{CA}+\mathrm{CR}$ & \multicolumn{3}{|c|}{$0.08(0.01)$} & \multicolumn{3}{|c|}{$0.10(0.01) a$} \\
\hline $\mathrm{SH}+\mathrm{SB}+\mathrm{CA}+\mathrm{CR}$ & \multicolumn{3}{|c|}{$0.08(0.00)$} & \multicolumn{3}{|c|}{0.08 (0.00)ab } \\
\hline $\mathrm{RC}+\mathrm{HV}+\mathrm{FR}+\mathrm{OA}$ & \multicolumn{3}{|c|}{$0.08(0.00)$} & \multicolumn{3}{|c|}{0.09 (0.01)ab } \\
\hline 8 species mix & \multicolumn{3}{|c|}{$0.08(0.01)$} & \multicolumn{3}{|c|}{$0.09(0.01) a b$} \\
\hline Contrast & Estimate & df & $p$-value & Estimate & df & $p$-value \\
\hline $\begin{array}{l}\text { Cover crops vs. no } \\
\text { cover crop control }\end{array}$ & 0.01 & 76 & 0.01 & 0.01 & 85 & 0.03 \\
\hline
\end{tabular}

Notes: Values within a column with different letters were significantly different based on Tukey's honestly significant difference $(p<0.05)$. The absence of letters in a column indicates that the effect of cover crop was not significant.

been due to lower biomass production in the fall by the legume cover crops compared to oat and forage radish (Finney et al. 2016) or unique influences of legume versus nonlegume cover crops on microbial communities. By spring, cover crops generally associated with higher proportions of AM fungi, protozoa, Gram-bacteria, and non-AM fungi were cereal rye, red clover, and hairy vetch (figure 2b). The winter-killed cover crops, namely soybean, sunn hemp, and forage radish, were associated with higher proportions of actinomycetes and Gram-positive bacteria (figure $2 b$ ). Again differences in biomass production by winter-killed versus winter-hardy cover crop species (Finney et al. 2016) may have led to this result in spring. In other words, cover crops that provided $\mathrm{C}$ inputs to the microbial community in both fall and spring led to higher proportions of AM fungi, protozoa, Gram-negative bacteria, and non-AM fungi in the soil microbial community by spring. By this logic, canola would have also been expected to promote increased proportions of these microbial groups, particularly in the spring, but, in fact, canola did not contribute to the differentiation of microbial communities along the first db-RDA axis in either season (figures $2 \mathrm{a}$ and $2 \mathrm{~b}$ ). One contributing factor to this result is the fact that AM fungi are obligate plant symbionts (Brundrett 2002) and members of the Brassicacae family such as canola and forage radish are not AM fungal hosts (Vierheilig et al. 2000). Previous research on standing crops and oilseed meals derived from glucosinalate-containing brassicas have indicated that members of this family can also alter bacterial community structure (Rumberger and Marschner 2003; Hollister et al. 2013), and a recent study comparing PLFA profiles of oat and rape (Brassica napus L.) cover crops found that rape was associated with larger populations of Gram-positive bacteria (Mackie et al. 2014). One hypothesis to explain the lack of a canola effect on microbial community composition in our study is that any increases in microbial groups generally associated with cover crops (i.e., Gram-negative bacteria, non-AM fungi, and protozoa, but not AM fungi) were offset by increases in Grampositive bacteria specific to this species.
There were several cover crop-microbial group associations indicated by the second $\mathrm{db}-\mathrm{RDA}$ (figures 2a and 2b) and supported by ANOVA results (tables 3 and 4). In fall, increasing oat biomass was associated with increasing proportions of AM fungi (figure 2a). Concentrations of the AM fungal biomarker were also significantly higher in the oat monoculture $\left(3.26 \pm 0.14 \mathrm{nmol} \mathrm{g}^{-1}\right)$ than the no cover crop control $(2.71 \pm 0.08 \mathrm{mnol}$ $\mathrm{g}^{-1}$ ) and tended to be higher in the oat monoculture than in other cover crop treatments (table 3). This finding supports previous work by Lehman et al. (2012) demonstrating that oat and oat-containing cover crop mixtures increased AM fungi in the fall. The current study also provided a means to evaluate the longevity of this effect by sampling in the spring. Similar to the results of the $\mathrm{db}-\mathrm{RDA}$ on treatment-level effects, the second axis of the db-RDA on species-specific effects was significant in spring and differentiated microbial communities based on the relative proportions of AM to non-AM fungi $(p=0.01$; figure $2 \mathrm{~b})$. Two cover crops were associated with higher proportions of AM fungi-oat and cereal rye (figure $2 b$ ). Oat and cereal rye monocultures also had higher concentrations of the AM fungal biomarker in spring $(3.66 \pm 0.33$ and $3.64 \pm 0.29 \mathrm{nmol}$ $\mathrm{g}^{-1}$, respectively) compared to the no cover crop control $\left(2.96 \pm 0.33 \mathrm{nmol} \mathrm{g}^{-1}\right)$, as did two cover crop mixtures, a four species mixture combining oats with forage radish, hairy vetch, and red clover $\left(3.68 \pm 0.39 \mathrm{nmol} \mathrm{g}^{-1}\right)$, and the eight species mixture $(3.92 \pm 0.44$ nmol g$\left.{ }^{-1}\right)$ that contained both oat and cereal rye (table 4). These results provide evidence that the positive effect of oat on AM fungi in the fall is not ephemeral, but persists into the spring. There is also evidence that the oat benefit, quantified as the density of mycorrhizal fungi, carries over into the subsequent crop in no-till sweet corn production (Kabir and Koide 2002). The same study also found that the density of mycorrhizal hyphae sampled in corn was higher following not only oat monocultures, but also cereal rye grown in monoculture and an oat-cereal rye biculture compared to a fallow control (Kabir and Koide 2002). A similar positive effect on mycorrhizal colonization of corn roots following a cereal rye cover crop has also been reported (White and Weil 2010), as has a positive effect of oats on AM-fungi propagules enumerated approximately three months after cover crop planting (Lehman et 


\section{Figure 2}

Distance-based redundancy analysis of soil microbial community composition as influenced by cover crop and weed biomass in (a) fall and (b) spring, approximately two and nine months, respectively, after cover crop planting in 2011 and 2012 in central Pennsylvania. Vectors indicate the degree of correlation between each factor and the axes. PLFA biomarker groups are indicated with a line and labeled in italics. Aboveground plant biomass by species is indicated with an arrow. In fall, plant species values represent the quantity of aboveground biomass produced in the fall by each cover crop species or arable weed community. In spring, plant species represent the sum of aboveground biomass produced in the fall and spring. Axes labeled with an asterisk are significant. $\mathrm{CA}=$ canola. $\mathrm{CR}=$ cereal rye. $\mathrm{FR}=$ forage radish. $\mathrm{HV}=$ hairy vetch. $\mathrm{NO}=$ no cover crop. $\mathrm{OA}=$ oat. $\mathrm{RC}=$ red clover. $\mathrm{SB}=$ soybean. $\mathrm{SH}=$ sunn hemp.

(a)

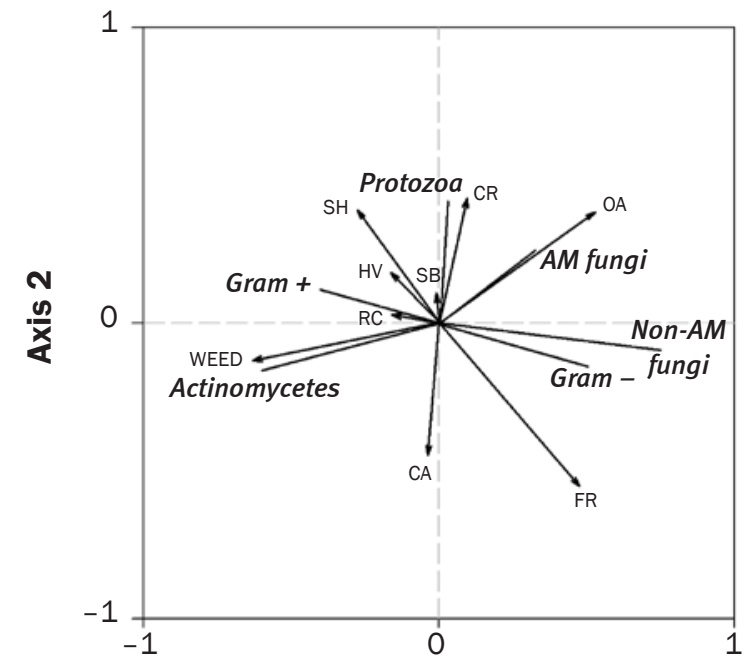

Axis 1* (b)

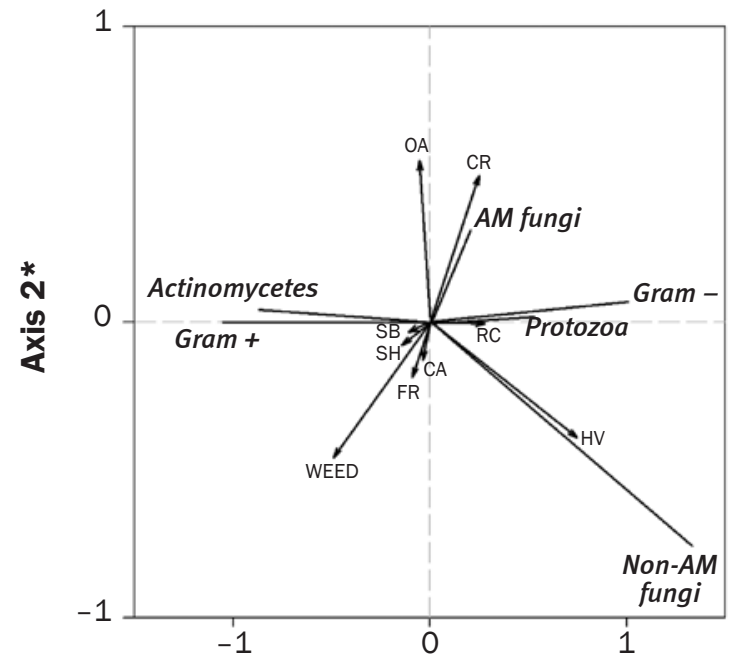

Axis 1* al. 2012). The fact that similar effects of oats and rye on AM fungal abundance have been detected using both microscopic (Kabir and Koide 2002; Lehman et al. 2012; White and Weil 2010) and biochemical (Lehman et al. 2012 and this study) quantification provides strong evidence that use of these cover crops is an effective strategy to increase AM fungi in agricultural systems. Unlike previous studies, however, we did not find that cover crop mixtures outperformed monocultures in the promotion of AM fungi (Kabir and Koide 2002; Lehman et al. 2012), though by spring, concentrations of the AM fungal biomarker tended to be highest in the most diverse (eight-species) cover crop mixture (table 4).

There was also an association between non-AM fungi and hairy vetch in the spring indicated by both db-RDA (figure $2 b$ ) and ANOVA (table 4). By spring, concentrations of the non-AM fungal biomarker were higher in the hairy vetch monoculture $(2.60$ $\left.\pm 0.35 \mathrm{nmol} \mathrm{g}^{-1}\right)$ than the no cover crop control $\left(1.42 \pm 0.31 \mathrm{nmol} \mathrm{g}^{-1}\right)$, oat monoculture $\left(1.28 \pm 0.20 \mathrm{nmol} \mathrm{g}^{-1}\right)$, and two mixtures. It is important to recognize that interpretation of PLFA biomarkers, particularly those used to identify AM and non-AM fungi, is challenged by the fact that biomarkers may be present in several microbial and nonmicro- bial groups (Frostegård et al. 2011). Recent work by Sharma and Buyer (2015) has shown that among three different lipid analyses (PLFA analysis [used in this study], neutral lipid fatty acid analysis [NLFA], and esterlinked fatty acid analysis [ELFA]), the PLFA biomarker did not correlate with two microscopic methods of quantifying AM-fungi in soil (spore counts) and plant roots (percentage colonization). Therefore, if the aim of a study is to estimate AM fungal spores or root colonization, NLFA or ELFA is advised. The PLFA biomarker for AM fungi used in this study has been found to indicate a viable fungal hyphal density and is a relevant indicator of abundance. The caveat associated with this biomarker, however, is that it is also found in Gram-negative bacteria and may overestimate AM fungal abundance (Buyer et al. 2010; Olsson 1999). The fact that Gramnegative and AM-fungi responded similarly to cover crop treatments and biomass in our study may reflect this overlap. In spite of this potential limitation of the PLFA biomarker, the species-specific associations we identified between AM fungi and oats and cereal rye are consistent with previous studies as noted earlier. The PLFA biomarker used to identify non-AM fungi is also present in plants; therefore, fine roots could contribute to the measured concentration of non-AM fungi. In a study in which it was found that the fungal PLFA biomarker increased in the presence of hairy vetch shoots in a tomato (Solanum lycopersicum L.) cropping system, Buyer et al. (2010) also used PLFA on cover crop plant tissues to demonstrate that plant roots contributed little to measured concentrations of the fungal biomarker in soil. This gives us confidence that the results we observed do indicate an association between hairy vetch and non-AM fungi. Comparison of non-AM fungi concentrations among treatments further indicates that this association was present not only in hairy vetch monocultures, but also in mixtures containing hairy vetch (table 4).

Based on our analyses, we conclude that cover crops generally serve to increase proportions of AM fungi, non-AM fungi, Gram-negative bacteria, and protozoa in the soil microbial community, but specific cover crops are associated with increases in specific microbial groups. The most notable associations are those of AM fungi with oats and with cereal rye and the association between non-AM fungi and hairy vetch. These cover crop-specific associations led to microbial communities that could be distinguished from one another based on their proportions 
of AM and non-AM fungi by spring (figures $1 b$ and $2 b$ ). Therefore, while cover crops appear to have a generally positive effect on fungal communities, cover crop species selection is a management strategy that can be used to increase targeted fungal groups.

The results of this study also raise a compelling question regarding the effects of multispecies cover crop mixtures on microbial diversity. If specific species promote distinct microbial communities, it would follow that microbial communities associated with cover crop mixtures would retain characteristics of each of the component species and, therefore, demonstrate greater diversity (Qiao et al. 2012; Zak et al. 2003). This idea is supported in our results by the fact that species-specific associations were manifest not only in monocultures, but also multispecies cover crop mixtures. For example, the location of cover crop mixtures combining hairy vetch and cereal rye along the second db-RDA axis in spring (figure $1 b$ ) was intermediate between hairy vetch and cereal rye monocultures, suggesting that the mixtures retained the fungal group associations specific to each of these species. Due to the limitations of PLFA (Frostegård et al. 2011), the question of microbial community diversity associated with cover crop mixtures will need to be addressed with molecular analytical tools; however, this study offers preliminary evidence that further investigation of the linkages between above and belowground diversity in cover cropping systems is warranted and relevant to improving soil health (Lehman et al. 2015a).

Soil Biological Activity. Soil biological activity, indicated by the daily respiration rate during a seven day incubation, differed among treatments in both fall and spring (table 6). In the fall, grass monocultures (oat and cereal rye) increased respiration by $50 \%$ relative to the control, and several mixtures also led to increases in activity ranging from $33 \%$ to $52 \%$. In spring, only three cover crop treatments exhibited increased respiration compared to the control: hairy vetch (17.06 $\pm 2.13 \mu \mathrm{g} \mathrm{CO}_{2}-\mathrm{C} \mathrm{g}^{-1}$ soil $\left.\mathrm{d}^{-1}\right)$ and cereal rye $\left(16.99 \pm 2.08 \mu \mathrm{g} \mathrm{CO}_{2}-\mathrm{C} \mathrm{g}^{-1}\right.$ soil $\left.\mathrm{d}^{-1}\right)$ monocultures and the four species mixture that contained both of these species (17.80 \pm $2.74 \mu \mathrm{g} \mathrm{CO}_{2}-\mathrm{C} \mathrm{g}^{-1}$ soil $\mathrm{d}^{-1}$; table 6), with an average increase of $36 \%$.

While there was a positive correlation between aboveground plant biomass and daily respiration (figure $3 \mathrm{a} ; r=0.39, p<0.01$ ), there was a stronger correlation between soil microbial biomass, indicated by total PLFA concentration, and biological activity (figure $3 \mathrm{~b} ; r=0.50, p<0.01)$. These results suggest that cover crops influence soil $\mathrm{C}$ utilization by providing labile $\mathrm{C}$ inputs to fuel respiration and the accumulation of soil microbial biomass, which, in turn, leads to increased respiration. There was, however, an even stronger positive correlation between respiration and fungal:bacterial ratio (figure $3 \mathrm{c} ; r$ $=0.82, p<0.01)$, an indicator of microbial community composition. This relationship was reflected in the fact that the cover crop treatment with the highest respiration rate in the spring, a four species mixture of hairy vetch, red clover, canola, and cereal rye, also exhibited the highest funal:bacterial ratio. Other treatments exhibiting high daily respiration rates in spring, hairy vetch and cereal rye monocultures, also tended to have higher fungal:bacterial ratios than the control. An important finding of this study, therefore, is that the influence of cover crops on $\mathrm{C}$ cycling is not confined to simply the quantity of C contributed to the soil, but also depends on species-specific plant-microbial associations like those we identified.

Arable Weeds and Microbial Community Composition. In addition to providing information on species-specific cover crop influences on microbial community composition, this study also advances our knowledge of the effects of arable weed communities on soil biology. In both fall and spring, increasing arable weed biomass was associated with higher proportions of Gram-positive bacteria and actinomycetes (figures $2 \mathrm{a}$ and $2 \mathrm{~b}$ ), a result consistent with the treatment-level $\mathrm{db}-\mathrm{RDA}$ (figures $1 \mathrm{a}$ and $1 \mathrm{~b}$ ). While the positive correlation between microbial biomass and plant productivity observed in this study would suggest that the arable weed community could serve a purpose similar to cover crops (i.e., providing sufficient $\mathrm{C}$ via exudates and fine root turnover to support microbial growth and activity), arable weeds and cover crops functioned differently with regard to the microbial groups with which they associated. The correlation between soil biological activity and greater fungal dominance indicates that these associations are, in fact, consequential to microbial community function and offers a mechanistic explanation for lower rates of activity observed in control treatments versus many of the cover cropped treatments in both fall and spring (table 6).

\section{Summary and Conclusions}

An important and relevant justification for the use of cover crops to improve soil health is that they provide resources to nourish soil microbial communities during periods when cash crops are not present. Arguably, arable weed communities that emerge in untilled fallows could perform this same function. This research demonstrates that cover crops perform an important function beyond simply providing resources to increase microbial biomass. Our work has shown that specific cover crops promote the abundance of specific groups of microorganisms and, therefore, can be used to direct microbial community composition toward assemblages that promote soil health. For example, rebuilding fungal populations that are typically depauperate in agricultural systems can promote SOM accumulation and enhance aggregate stability. The results of this study show that cover crops generally lead to increased concentrations of soil fungi compared to arable weeds, with the greatest gains associated with oats, hairy vetch, and cereal rye. Notably, our results also offer evidence that different fungal communities respond to different cover crop species. While cereal rye and oats were associated with increases in AM fungi, hairy vetch, and to a lesser extent red clover, led to increased abundance of non-AM fungi. Knowledge of these species-specific cover crop influences will enable land managers to design cover cropping systems that can efficiently and effectively manipulate soil biology to enhance soil health.

\section{Acknowledgements}

We thank the staff of the Russell E. Larson Agricultural Research Center in Pennsylvania, Brosi Bradley (research technician, Penn State University, State College, Pennsylvania), Sara Eckert (owner, Healthy Harvest Farm, Bellefonte, Pennsylvania), Stanley Tesch (research technician, USDA Agricultural Research Service, Beltsville, Maryland), Riley Mummah and Jillian Oakland (statistical consultants, Penn State University, State College, Pennsylvania), and numerous undergraduate assistants for data collection and technical assistance. This project was funded by grants to Denise M. Finney from the Northeast Sustainable Agriculture Research and Education graduate research program (GNE11-017) and the Penn State College of Agricultural Sciences. Finney also received support from the USDA National Institute of Food and Agriculture (NIFA) predoctoral fellowship program (2012-67011-19662) and the ARCS Foundation, Pittsburgh Chapter. 


\section{Table 6}

Main effects of year and cover crop treatment on least square means and standard errors (standard errors are values in parentheses) of daily respiration rate $\left(\mu \mathrm{g} \mathrm{CO}-\mathrm{C} \mathrm{g}^{-1}\right.$ soil d $\left.{ }^{-1}\right)$ during a seven day incubation of fresh soil collected in fall and spring, approximately two and nine months, respectively, following cover crop planting in August of 2011 (Year 1) and August of 2012 (Year 2) in central Pennsylvania.

\begin{tabular}{|c|c|c|c|c|c|c|}
\hline Year/crop & \multicolumn{3}{|l|}{ Fall } & \multicolumn{3}{|l|}{ Spring } \\
\hline Year 1 & \multicolumn{3}{|c|}{$13.11(0.32) a$} & \multicolumn{3}{|c|}{17.97 (0.64)a } \\
\hline Year 2 & \multicolumn{3}{|c|}{$7.69(0.23) \mathrm{b}$} & \multicolumn{3}{|c|}{$8.05(0.37) \mathrm{b}$} \\
\hline No cover crop & \multicolumn{3}{|c|}{$8.06(1.15) d$} & \multicolumn{3}{|c|}{$11.14(3.39) \mathrm{cde}$} \\
\hline Sunn hemp (SH) & \multicolumn{3}{|c|}{$8.59(1.37) \mathrm{cd}$} & \multicolumn{3}{|c|}{$9.98(2.05) \mathrm{e}$} \\
\hline Soybean (SB) & \multicolumn{3}{|c|}{$9.22(1.31) \mathrm{bcd}$} & \multicolumn{3}{|c|}{$9.44(1.77) \mathrm{e}$} \\
\hline Red clover (RC) & \multicolumn{3}{|c|}{$8.67(0.98) \mathrm{cd}$} & \multicolumn{3}{|c|}{$11.50(1.63) \mathrm{cde}$} \\
\hline Hairy vetch (HV) & \multicolumn{3}{|c|}{9.73 (1.33)abcd } & \multicolumn{3}{|c|}{$17.06(2.13) a b$} \\
\hline Forage radish (FR) & \multicolumn{3}{|c|}{10.21 (0.79)abcd } & \multicolumn{3}{|c|}{10.33 (1.46)ef } \\
\hline Oat $(\mathrm{OA})$ & \multicolumn{3}{|c|}{$11.92(1.54) a b$} & \multicolumn{3}{|c|}{12.67 (2.77)abcde } \\
\hline Canola (CA) & \multicolumn{3}{|c|}{9.80 (1.00)abcd } & \multicolumn{3}{|c|}{$11.23(1.83) \mathrm{cde}$} \\
\hline Cereal rye (CR) & \multicolumn{3}{|c|}{$12.28(1.18) a$} & \multicolumn{3}{|c|}{16.99 (2.08)ab } \\
\hline $\mathrm{FR}+\mathrm{OA}+\mathrm{CA}+\mathrm{CR}$ & \multicolumn{3}{|c|}{10.97 (1.16)abc } & \multicolumn{3}{|c|}{$12.37(1.45) \mathrm{bcde}$} \\
\hline $\mathrm{SH}+\mathrm{SB}+\mathrm{FR}+\mathrm{OA}$ & \multicolumn{3}{|c|}{$12.20(1.16) \mathrm{a}$} & \multicolumn{3}{|c|}{$11.31(2.38) \mathrm{cde}$} \\
\hline $\mathrm{RC}+\mathrm{HV}+\mathrm{CA}+\mathrm{CR}$ & \multicolumn{3}{|c|}{11.89 (1.50)ab } & \multicolumn{3}{|c|}{$17.80(2.74) \mathrm{a}$} \\
\hline $\mathrm{SH}+\mathrm{SB}+\mathrm{CA}+\mathrm{CR}$ & \multicolumn{3}{|c|}{10.12 (1.08)abcd } & \multicolumn{3}{|c|}{14.00 (1.84)abcde } \\
\hline $\mathrm{RC}+\mathrm{HV}+\mathrm{FR}+\mathrm{OA}$ & \multicolumn{3}{|c|}{10.73 (1.37)abcd } & \multicolumn{3}{|c|}{14.56 (2.65)abcd } \\
\hline 8 species mix & \multicolumn{3}{|c|}{11.61 (1.32)ab } & \multicolumn{3}{|c|}{$15.92(3.06) \mathrm{abc}$} \\
\hline Contrast & Estimate & df & $p$-value & Estimate & df & $p$-value \\
\hline $\begin{array}{l}\text { Cover crops vs. no } \\
\text { cover crop control }\end{array}$ & 2.51 & 84 & $<0.01$ & 2.01 & 90 & 0.10 \\
\hline
\end{tabular}

Notes: Values within a column with different letters were significantly different due to year or cover crop based on Tukey's HSD $(p<0.05)$. The absence of letters in a column indicates that the effect of year or cover crop was not significant.

\section{References}

Berg, G., and K. Smalla. 2009. Plant species and soil type cooperatively shape the structure and function of microbial communities in the rhizosphere. Federation of European Microbiological Societies (FEMS) Microbiology Ecology 68(1):1-13.

Bezemer, T.M., M.T. Fountain, J.M. Barea, S. Christensen, S.C. Dekker, H. Duyts, R. van Hal, J.A. Harvey, K. Hedlund, M. Maraun, J. Mikola, A.G. Mladenov, C. Robin, P.C. de Ruiter, S. Scheu, H. Setälä, P. Šmilauer, and W.H. van der Putten. 2010. Divergent composition but similar function of soil food webs of individual plants: Plant species and community effects. Ecology 91(10):3027-36

Borcard, D., F. Gillet, and P. Legendre. 2011. Numerical Ecology with R. New York: Springer.

Bossio, D.A., K.M. Scow, N. Gunapala, and K.J. Graham. 1998. Determinants of soil microbial communities: Effects of agricultural management, season, and soil type on phospholipid fatty acid profiles. Microbial Ecology 36(1):1-12.

Brundrett, M.C. 2002. Tansley review No. 134. Coevolution of roots and mycorrhizas of land plants. New Phytologist 154(2):275-304

Buyer, J.S., D.P. Roberts, and E. Russek-Cohen. 2002. Soil and plant effects on microbial community structure. Canadian Journal of Microbiology 48(11):955-64.

Buyer, J.S., and M. Sasser. 2012. High throughput phospholipid fatty acid analysis of soils. Applied Soil Ecology 61:127-30.

Buyer, J.S., J.R. Teasdale, D.P. Roberts, I.A. Zasada, and J.E. Maul. 2010. Factors affecting soil microbial community

\section{Figure 3}

Correlation of soil biological activity to (a) plant biomass, (b) microbial community size, and (c) microbial community composition in soils collected two and nine months after cover crop planting in 2011 and 2012 in central Pennsylvania. Soil biological activity was measured as the daily respiration rate in a seven day laboratory incubation of fresh soil. (a) Plant biomass is the sum of aboveground cover crop and weed biomass produced in the season (fall or spring) in which soil was collected. (b) Total phospholipid fatty acid (PLFA) concentration represents the size of the microbial community, and (c) the fungal:bacterial ratio of the microbial community represents community composition.

(a)

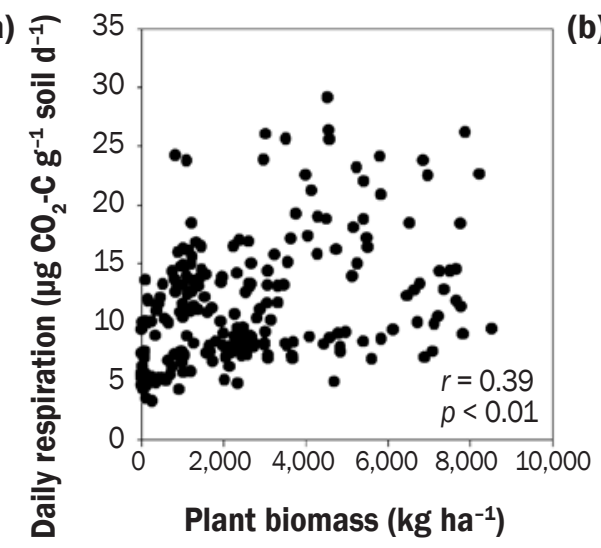

(b)

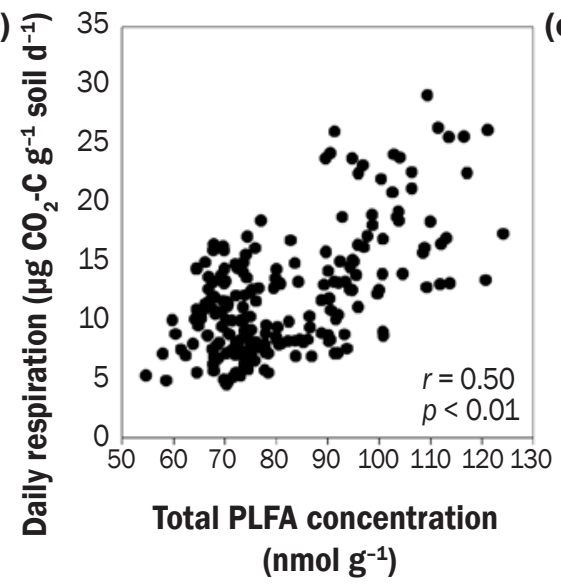

(c)

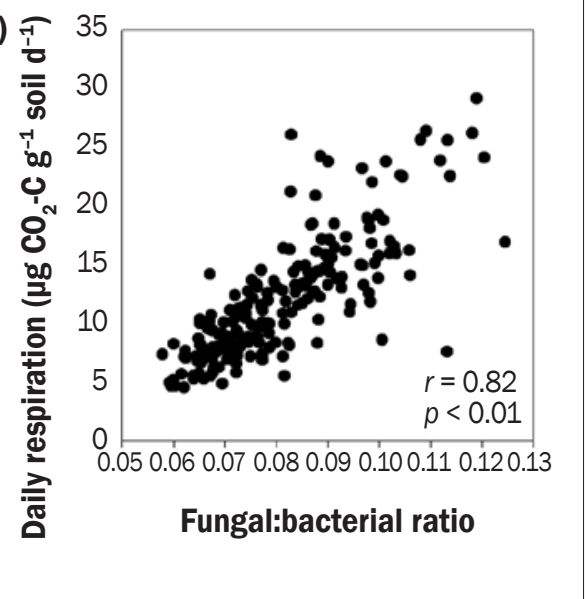


structure in tomato cropping systems. Soil Biology and Biochemistry 42(5):831-41.

Carrera, L.M., J.S. Buyer, B. Vinyard, A.A. Abdul-Baki, L.J. Sikora, and J.R. Teasdale. 2007. Effects of cover crops, compost, and manure amendments on soil microbial community structure in tomato production systems. Applied Soil Ecology 37(3):247-55.

Denef, K., D. Roobroeck, M.C.W. Manimel Wadu, P. Lootens, and P. Boeckx. 2009. Microbial community composition and rhizodeposit-carbon assimilation in differently managed temperate grassland soils. Soil Biology and Biochemistry 41(1):144-53.

Doran, J.W., M. Sarrantonio, and M. Liebig. 1996. Soil health and sustainability. In Advances in Agronomy, ed. D.L. Sparks, 1-54. San Diego:Academic Press.

Drenovsky, R.E., D. Vo, K.J. Graham, and K.M. Scow. 2004. Soil water content and organic carbon availability are major determinants of soil microbial community composition. Microbial Ecology 48(3):424-30.

Eisenhauer, N., H. Beßler, C. Engels, G. Gleixner, M. Habekost, A. Milcu, S. Partsch, A.C.W. Sabais, C. Scherber, S. Steinbeiss, A. Weigelt, W.W. Weisser, and S. Scheu. 2010. Plant diversity effects on soil microorganisms support the singular hypothesis. Ecology 91(2):485-96.

Fierer, N., M.A. Bradford, and R.B. Jackson. 2007. Toward an ecological classification of soil bacteria. Ecology 88(6):1354-64.

Fierer, N., and R.B. Jackson. 2006. The diversity and biogeography of soil bacterial communities. Proceedings of the National Academy of Sciences of the United States of America 103(3):626-31.

Finney, D.M., C.M. White, and J.P. Kaye. 2016. Biomass production and carbon/nitrogen ratio influence ecosystem services from cover crop mixtures. Agronomy Journal 108(1):39-52.

Frostegård, Å., A. Tunlid, and E. Bååth. 2011. Use and misuse of PLFA measurements in soils. Soil Biology and Biochemistry 43(8):1621-25.

Girvan, M.S., J. Bullimore, J.N. Pretty, A.M. Osborn, and A.S. Ball. 2003. Soil type us the primary determinant of the composition of the total and active bacterial communities in arable soils. Applied and Environmental Microbiology 69(3):1800-1809.

Grayston, S., C.D. Campbell, R.D. Bardgett, J.L. Mawdsley, C.D. Clegg, K. Ritzc, B.S. Griffiths, J.S. Rodwell, S.J. Edwards, W.J. Davies, D.J. Elston, and P. Millard. 2004. Assessing shifts in microbial community structure across a range of grasslands of differing management intensity using CLPP, PLFA and community DNA techniques. Applied Soil Ecology 25(1):63-84.

Hollister, E.B., P. Hu, A.S. Wang, F.M. Hons, and T.J. Gentry. 2013. Differential impacts of brassicaceous and nonbrassicaceous oilseed meals on soil bacterial and fungal communities. Federation of European Microbiological Societies (FEMS) Microbiology Ecology 83(3):632-41.
Ingels, C.A., K.M. Scow, D.A. Whisson, and R.E. Drenovsky. 2005. Effects of cover crops on grapevines, yield, juice composition, soil microbial ecology, and gopher activity. American Journal of Enology and Viticulture 56(1):19-29.

Joergensen, R.G., and F. Wichern. 2008. Quantitative assessment of the fungal contribution to microbial tissue in soil. Soil Biology and Biochemistry 40(12):2977-91.

Kabir, Z., and R.T. Koide. 2000. The effect of dandelion or a cover crop on mycorrhiza inoculum potential, soil aggregation and yield of maize. Agriculture, Ecosystems and Environment 78:167-74.

Kabir, Z., and R.T. Koide. 2002. Effect of autumn and winter mycorrhizal cover crops on soil properties, nutrient uptake and yield of sweet corn in Pennsylvania, USA. Plant and Soil 238:205-15.

Kabir, Z., I.P. O'Halloran, and C. Hamel. 1997. Overwinter survival of arbuscular mycorrhizal hyphae is favored by attachment to roots but diminished by disturbance. Mycorrhiza 7(4):197-200.

Kong, A.Y., and J. Six. 2012. Microbial community assimilation of cover crop rhizodeposition within soil microenvironments in alternative and conventional cropping systems. Plant and Soil 356(1-2):315-30.

Lehman, R.M., W.I. Taheri, S.L. Osborne, J.S. Buyer, and D.D. Douds Jr. 2012. Fall cover cropping can increase arbuscular mycorrhizae in soils supporting intensive agricultural production. Applied Soil Ecology 61:300-304

Lehman, R.M., V. Acosta-Martínez, J.S. Buyer, C.A. Cambardella, H.P. Collins, T.F. Ducey, J.J. Halvorson, V.L. Jin, J.M.F. Johnson, R.J. Kremer, J.G. Lundgren, D.K. Manter, J.E. Maul, J.L. Smith, and D.E. Stott. 2015a. Soil biology for resilient, healthy soil. Journal of Soil and Water Conservation 70(1):12A-18A, doi:10.2489/ jswc.70.1.12A

Lehman, R.M., C.A. Cambardella, D.E. Stott, V. AcostaMartinez, D.K. Manter, J.S. Buyer, J.E. Maul, J.L. Smith, H.P. Collins, J.J. Halvorson, R.J. Kremer, J.G. Lundgren, T.F. Ducey, V.L. Jin, and D.L. Karlen. 2015b. Understanding and enhancing soil biological health:The solution for reversing soil degradation. Sustainability 7(1):988-1027.

Lennon, J.T., Z.T. Aanderud, B.K. Lehmkuhl, and D.R. Schoolmaster. 2012. Mapping the niche space of soil microorganisms using taxonomy and traits. Ecology 93(8):1867-79.

Lienhard, P., S. Terrat, N. Chemidlin Prévost-Bouré, V. Nowak, T. Régnier, S. Sayphoummie, K. Panyasiri, F. Tivet, O. Mathieu, J. Levêque, P.A. Maron, and L. Ranjard. 2014. Pyrosequencing evidences the impact of cropping on soil bacterial and fungal diversity in Laos tropical grassland. Agronomy for Sustainable Development 34(2):525-33.

Mackie, K.A., H.P. Schmidt, T. Müller, and E. Kandeler. 2014. Cover crops influence soil microorganisms and phytoextraction of copper from a moderately contaminated vineyard. Science of the Total Environment 500-501:34-43.

Maul, J.E., J.S. Buyer, R.M. Lehman, S. Culman, C.B. Blackwood, D.P. Roberts, I.A. Zasada, and J.R. Teasdale. 2014. Microbial community structure and abundance in the rhizosphere and bulk soil of a tomato cropping system that includes cover crops. Applied Soil Ecology 77:42-50.

Maul, J.E., and L.E. Drinkwater. 2010. Short-term plant species impact on microbial community structure in soils with long-term agricultural history. Plant and Soil 330(1-2):369-82.

McCune, B., and J.B. Grace. 2002. Analysis of Ecological Communities. Gleneden Beach, OR: MjM Software.

McDaniel, M.D., J.P. Kaye, M.W. Kaye, and M.A. Bruns. 2014a. Climate change interactions affect soil carbon dioxide efflux and microbial functioning in a postharvest forest. Oecologia 174(4):1437-48.

McDaniel, M.D., L.K. Tiemann, and A.S. Grandy. 2014b. Does agricultural crop diversity enhance soil microbial biomass and organic matter dynamics ? A meta-analysis. Ecological Applications 24(3):560-70.

Nair, A., and M. Ngouajio. 2012. Soil microbial biomass, functional microbial diversity, and nematode community structure as affected by cover crops and compost in an organic vegetable production system. Applied Soil Ecology 58:45-55.

Olsson, A. 1999. Signature fatty acids provide tools for determination of the distribution and interactions of mycorrhizal fungi in soil. Federation of European Microbiological Societies (FEMS) Microbiology Ecology 29:303-10.

Qiao, Y.J., Z.Z. Li, X. Wang, and B. Zhu. 2012. Effect of legume-cereal mixtures on the diversity of bacterial communities in the rhizosphere. Plant, Soil and Environment 58:174-80.

R Development Core Team. 2013. R: A Language and Environment for Statistical Computing. Vienna, Austria: R Foundation for Statistical Computing.

Regan, K.M., N. Nunan, R.S. Boeddinghaus, V. Baumgartner, D. Berner, S. Boch, Y. Oelmann, J. Overmann, D. Prati, M. Schloter, B. Schmitt, E. Sorkau, M. Steffens, E. Kandeler, and S. Marhan. 2014. Seasonal controls on grassland microbial biogeography: Are they governed by plants, abiotic properties or both? Soil Biology and Biochemistry 71:21-30.

Rillig, M.C. 2004. Arbuscular mycorrhizae and terrestrial ecosystem processes. Ecology Letters 7:740-54.

Rumberger, A., and P. Marschner. 2003. 2-phenylethylisothiocyanate concentration and microbial community composition in the rhizosphere of canola. Soil Biology and Biochemistry 35(3):445-52.

Saison, C., V. Degrange, R. Oliver, P. Millard, C. Commeaux, and X.Le Roux. 2006.Alteration and resilience of the soil microbial community following compost amendment: 
Effects of compost level and compost-borne microbia community. Environmental Microbiology 8(2):247-57.

Schipanski, M.E., M. Barbercheck, M.R. Douglas, D.M.

Finney, K. Haider, J.P. Kaye, A.R. Kemanian, D.A Mortensen, M.R. Ryand, J. Tooker, and C. White. 2014. A Framework for evaluating ecosystem services provided by cover crops in agroecosystems. Agricultural Systems 125:12-22.

Schutter, M.E., J.M. Sandeno, and R.P. Dick. 2001. Seasonal, soil type, and alternative management influences on microbial communities of vegetable cropping systems. Biology and Fertility of Soils 34(6):397-410.

Searle, S.R., F.M. Speed, and G.A. Milliken. 1980. Population marginal means in the linear model: An alternative to least squares means. The American Statistician 34(4):216-21.

Sharma, M.P., and J.S. Buyer. 2015. Comparison of biochemical and microscopic methods for quantification of arbuscular mycorrhizal fungi in soil and roots. Applied Soil Ecology 95:86-89.

Six, J., E.T. Elliott, and K. Paustian. 1999. Aggregate and soil organic matter dynamics under conventional and no-tillage systems. Soil Science Society of America Journal 63:1350-58

Six, J., S.D. Frey, R.K. Thiet, and K.M. Batten. 2006. Bacterial and fungal contributions to carbon sequestration in agroecosystems. Soil Science Society of America Journal 70:555-69.

Tiemann, L.K., A.S. Grandy, E.E. Atkinson, E. Marin-Spiotta, and M.D. McDaniel. 2015. Crop Rotational Diversity Enhances Belowground Communities and Functions in an Agroecosystem. Ecology Letters 18:761-71.

Treonis, A.M., E.E. Austin, J.S. Buyer, J.E. Maul, L. Spicer, and I.A. Zasada. 2010. Effects of organic amendment and tillage on soil microorganisms and microfauna. Applied Soil Ecology 46(1):103-10.

USDA NRCS (Natural Resources Conservation Service). 2012. Farming in the 21st Century. Washington, DC: USDA.

Vierheilig, H., R. Bennett, G. Kiddle, M. Kaldorf, and J. Ludwig-Muller. 2000. Differences in glucosinolate patterns and arbuscular mycorrhizal status of glucosinolate-containing plant species. New Phytologist 146(2):343-52.

Wang, Q.R., Y.C. Li, and W. Klassen. 2007. Changes of soil microbial biomass carbon and nitrogen with cover crops and irrigation in a tomato field. Journal of Plant Nutrition 30(4):623-39.

Wardle, D.A., R.D. Bardgett, J.N. Klironomos, H. Setala, W.H. van der Putten, and D.H. Wall. 2004. Ecological linkages between aboveground and belowground biota. Science 304(5677):1629-33.

Weitzman, J.N., K.J. Forshay, J.P. Kaye, P.M. Meyer, J.C. Koval, and R.C. Walter. 2014. Potential nitrogen and carbon processing in a landscape rich in milldam legacy sediments. Biogeochemistry 120(1-3):337-57.
White, C.M., and R.R. Weil. 2010. Forage radish and cereal rye cover crop effects on mycorrhizal fungus colonization of maize roots. Plant Soil 328:507-21.

Wortman, S.E., R.A. Drijber, C.A. Francis, and J.L. Lindquist. 2013. Arable weeds, cover crops, and tillage drive soil microbial community composition in organic cropping systems. Applied Soil Ecology 72:232-41.

Zak, D.R., W. Holmes, D.C. White, and D. Tilman. 2003. Plant diversity, soil microbial communities, and ecosystem function: Are there any links? Ecology 84(8):2042-50.

Zelles, L. 1999. Fatty acid patterns of phospholipids and lipopolysaccharides in the characterisation of microbial communities in soil: A review. Biology and Fertility of Soils 29:111-29.

Zelles, L., A. Palojärvi, E. Kandeler, M. von Lützow, K. Winter, and Q.Y. Bai. 1997. Changes in soil microbial properties and phospholipid fatty acid fractions after chloroform fumigation. Soil Biology and Biochemistry 29(9-10):1325-1336. 